\title{
Farklı Mevsim ve Barınak Sistemlerinin Siyah Alaca Erkek Danaların Besi Gücü ve Kesim Özelliklerine Etkileri
}

\author{
Ahmet GÜRBÜZ1 Numan AKMAN² $\quad$ A.Hadi BAŞARAN ${ }^{1} \quad$ Durmuş ÖZTÜRK'
}

Geliş Tarihi : 16.09.1998

\begin{abstract}
Özet: Bu araştırma, mevsim (kış ve yaz) ile barınak tipinin (açık, yarı açık ve kapalı) 8-8.5 aylık yaşta besiye alınan Siyah Alaca erkek danaların besi gücü ve kesim özeliikleri üzerine etkilerini saptamak amacıyla Tarla Bitkileri Merkez Araştırma Enstitüsünde yürütülmüş̧ür. Grupların hepsine, 168 gün sürdürülen besi süresince, günde hayvan başına $2 \mathrm{~kg}$ karma yem ve $1 \mathrm{~kg}$ arpa samanına ek olarak ad-libitum düzeyde arpa kırması yedirilmiştir.

Besi boyunca toplam ve günlük canlı ağırlık artışı, $1 \mathrm{~kg}$ canlı ağırlık artişı için kuru madde tüketimi, (arpa +saman+ karma yem) soğuk karkas randımanı ve böbrek-leǧen yağları ağırlığı; kış mevsiminde besiye alınanlarda sırasıyla 209 $\mathrm{kg}, 1243 \mathrm{~g}, 6.75 \mathrm{~kg}, \% 57.1$ ve $4.68 \mathrm{~kg}$; yaz mevsiminde besiye alınanlarda ise aynı sırayla $204 \mathrm{~kg}, 1213 \mathrm{~g}, 6.79 \mathrm{~kg}, \%$ 56.8 ve $3.68 \mathrm{~kg}$ olmuştur. Söz konusu özelliklerin değerleri yine aynı sırayla sundurmalı açık ahırda beslenenlerde 191 $\mathrm{kg}, 1138 \mathrm{~g}, 7.36 \mathrm{~kg}, \% 56.6$ ve $3.52 \mathrm{~kg}$; yarı açık barınak grubunda $216 \mathrm{~kg}, 1286 \mathrm{~g}, 6.42 \mathrm{~kg}, \% 57.1$ ve $4.18 \mathrm{~kg}$; kapalı barınak grubunda da $212 \mathrm{~kg}, 1260 \mathrm{~g}, 6.53 \mathrm{~kg}, \% 56.8$ ve $4.63 \mathrm{~kg}$ olarak hesaplanmıştır.
\end{abstract}

Anahtar Kelimeler: Siyah-Alaca, besi, ahir tipi, mevsim

\section{Effects of Seasons and Housing Types on the Fattening Performance and Carcass Characteristics of Holstein Friesian Bulls}

\begin{abstract}
This research was conducted to investigate the effects of housing types (three side open with no shelter, one side open with shelter and closed barn) and the seasons of fattening (winter and summer) on the fattening performance and slaughter characteristics of 8-8.5 month-old Black and White bulis in Field Crops Central Research Institute, Ankara. The animals were fed $1 \mathrm{~kg}$ straw and $2 \mathrm{~kg}$ concentrates daily in addition to ad libitum barley during the 24 weeks of fattening period.

During the fattening period; total weight gain, daily gain, dry matter intakes (barley + straw + concentrate) for one $\mathrm{kg}$ live weight gain were found as $209 \mathrm{~kg}, 1243 \mathrm{~g}, 6.75 \mathrm{~kg}$ winter group, $204 \mathrm{~kg}, 1213 \mathrm{~g}, 6.79 \mathrm{~kg}$ in summer group, 191 $\mathrm{kg}, 1138 \mathrm{~g}, 7.36 \mathrm{~kg}$ in the group housed in three side open with no shelter barn, $216 \mathrm{~kg}, 1286 \mathrm{~g}, 6.42 \mathrm{~kg}$ in the group housed in one side open with shalter barn, $212 \mathrm{~kg}, 1260 \mathrm{~g}, 6.53 \mathrm{~kg}$ in the group housed in closed barn, respectively. The averages dressing percentage (from cold carcass weight) and pelvic fat were calculated as $57.1 \%$ and $4.68 \mathrm{~kg}$ in winter group, $56.8 \%$, and $3.68 \mathrm{~kg}$ in summer group, $56.6 \%$ and $3.52 \mathrm{~kg}$ in the group housed in three side open with no shelter barn, $57.1 \%$ and $4.18 \mathrm{~kg}$ in the group housed in one side open with shelter barn, $56.8 \%$ and $4.63 \mathrm{~kg}$ in the group housed in closed barn, respectively.
\end{abstract}

Key Words: Holstein Friesian, fattening, housing types, season

\section{Giriş}

Türkiye de sığir besisi faaliyetleri, hemen tamamen, bu amaçla kuruimuş işletmelerde yürütülmektedir. Genellikle kapalı ahıllarla çalışmayı tercih eden sığır besisi işletmeleri, zaten kısıttı olan sermayelerinin önemli bir bölümünü veya tamamını ahır inşaatına harcamakta ve sabit yatırım tamamlandığında yeterli düzeyde işletme sermayesi bulamaz hale gelmektedirler. Sonuçta işletmeler, ya üretime başlayamamakta, ya borçlanmakta ya da temel üretim girdilerinin kullanımında kısıntıya gitmektedir. Kısaca, mevcut sermayenin yanlış kullanımı nedeniyle, işletme sermayesi bulamaz hale gelen yatıımcıların, işin sürekliliği ve büyümesini sağlamaları tehlikeye girmektedir. Türkiye'de besicilik sektöründe, üretim düşüklügü, maliyetin yüksekliği ve ahırların boş kalması biçiminde gündeme gelen problemlerin temelinde bu çelişkinin, bir başka ifade ile, zaten kısıtlı olan sermayenin kullanımında pahalı barınak inşaatına öncelik verilmesinin büyük payı vardır (Yener ve Akman 1990).

Sığır besisi amaçlı barınak yapımında tercihin kapalı ahırlar yönünde kulianilmasının tek sakıncası, sermayenin etkin kullanılamaması değildir. Buna ek olarak, özellikle hayvanları soğuktan koruma kaygısıyla, neredeyse mutlak manada kapalı olarak inşa edilen ahırlarda, yaz aylarında ahır içi sıcaklığının iyice yükselmesi ve havalandırmanın yetersiz kalması sonucu ahır içinde oluşan zararlı gazların dışarı atılamaması da beside yem tüketimi, özellikle de yem değerlendirmeyi düşürerek besi ekonomisini olumsuz etkilemektedir (Yener ve Akman 1990, Akcan 1986, Olgun 1989).

Her hangi bir hayvansal üretim dalında barınak yapmanın temel gerekçeleri; iklim unsurlarının olumsuz

\footnotetext{
1 Tarla Bitkileri Merkez Araştırma Enstitüsü, Ankara

${ }^{2}$ Ankara Univ. Ziraat Fak. Zootekni Bölümü, Ankara
} 
etkisini en aza indirmek, hayvanlar üzerinde denetim sağlayabilmek ve işletmedeki günlük işleri daha kolay ve az işgücü kullanarak gerçekleştirmektir. Bu hususlara en iyi karşılık verecek barınak tipi araştırilırken öncelikle hayvanların, başta soğuk olmak üzere, çeşitli iklim unsurlarından nasıl etkilendiği üzerinde durulmalıdır

Türkiye'de her nasilsa, bütün hayvansal üretim dallarında, düşük sıcaklık, hangi seviyede olduğuna bakılmaksızın, zararlı bir çevre faktörü olarak algılanmış, kredi kaynakları bile soğuktan korumayı ön plana çıkaran yapılar için kullandırımıştır. Sığır da, uzun süre, bu anlayışın dışında kalamamış, ancak son yıllarda açık ve yarı açık ahırlar için de kredi verilmeye başlanmış, hatta bu sistemleri özendirecek çalışmalar yoğunlaştırılmıştır. Ne var ki yetiştiricilerin, yılların birikimi olan alışkanlıklarını kolayca terk edeceklerini ve kisa sürede, geçim kaynaklarını oluşturan hayvaniarını, hakkında yeterli bilgi sahibi olmadikları, hatta zararlı bildikieri bir ahırda barındırmaya başlayacaklarını beklemek de pek akılcı değildir. Nitekim bu konuda tartışmalar bitmemiş, kaygılar henüz ortadan kaldırılamamıştır. Bu eksikliğin giderebilmesi için bir yandan sığırların çevre isteklerine ilişkin doğru bilgilerin üreticilere ulaştırılması, diğer yandan da bu tip barınakların besi performasının üzerine etkilerini ortaya koyacak deneysel çalışmalara ağırlık verilmesi gerekmektedir (Kendir ve ark. 1973, Uludağ 1973, Hotaman 1991, Tüzemen ve ark. 1992, Akcan ve ark. 1992).

Açıkta barındırılacak sığırlar, doğal olarak, yörede hakim iklim koşullarının (sıcaklık, yağış, nem vb.) etkisi altında olacaktır. Bu tip iklim unsurlarından en belirginleri, yaz ayları için sıcak, kış ayları için de soğuktur. Bunlara ek olarak, hemen her mevsimde yağış, rüzgar ve nisbi nem de, açıkta barındırılan hayvanları doğrudan etkileyecektir.

Hayvanlarin fizyolojik faaliyetlerini en üst seviyede gerçekleştirilebildikleri sıcaklık dereceleri yaş, ırk, cüsse ve verim yönüne göre değişir. Bütün türler için, genellikle oldukça dar olan bu sicaklik bölgesi dişında da, hayvanların fizyolojik faaliyetlerini, ciddi engellerle karşılaşmadan, sürdürebildikleri sıcaklık bölgeleri vardır (Akcan 1986, Mutaf ve ark. 1984, Robertshaw 1981). "Uygun sıcaklık bölgesi" olarak adlandırılan bu bölgenin alt ve üst sıcaklık değerleri, besideki sığırlarda $-90^{\circ}$ ve $+24{ }^{\circ} \mathrm{C}$ dir (Buclin ve ark. 1992). Yalnız bu sınırların dışında kalan sıcaklık bölgelerinde hayvanların yaşayamayacakları düşünülmemelidir. Uygun sıcaklık bölgelerinin dışında sıcaklıklara maruz kalan hayvanlar, sahip oldukları birtakım savunma mekanizmalarını harekete geçirerek yaşamlarını sürdürmeye çalışır (Buclin ve ark 1992. Butchbaker ve ark. 1973, Hardy ve Meadowcraft 1986, Okuroğlu ve Delibaş 1986). Örneğin, daha soğuk koşullarda vücut sıcaklığını korumak için yem tüketimini yükseltirken, uygun bölge üst sıcaklık derecesinden daha yüksek sicaklıklarda ise, vücut sıcaklığının yükselişini önlemek veya vücut sıcaklığını düşürmek için yem tüketimi azaltır, solunum sayısını yükseltirler. Ölüm, ancak bu önlemler yetersiz kaldığında şekillenir. Sığırlar için ölümün şekilleneceği değerler, özellikle soğuk açısından, Türkiye'de hemen hiç rastlanmayan sıcaklık dereceleridir. Bir başka ifadeyle, Türkiye'de yürütülecek sığır besiciliğinde, besi tamamen açık bir alanda yürütülse bile, soğuk, ilk bakışta ciddi bir kısıtlayıcı unsur değildir.

Sığır besisine ilişkin bilgilerin artması yanında, barınak yatırım maliyetlerinin, buna bağlı olarak da besi barınaklarının inşaatı için verilen kredi ve desteklerin parasal tutarının iyice yükselmesi, hem besicileri hem de ilgili kamu kuruluşlarını yeni arayışlara sevk etmiştir. Bu arayışların doğal sonucu olarak değişik ahır tiplerinin, örneğin, tamamen açık, sundurmalı, yarı açık ve kapalı ahırların besi performansıne etkilerini karşılaştırmaya yönelik araştırmalar yürütülmüştür (Kendir ve ark. 1973, Uludağ 1973, Hotaman 1991, Tüzemen ve ark. 1992, Akcan ve ark. 1992, Başaran 1994). Lalahan Zootekni Araştırma Enstitüsünde yürütülen bir çalışmada (Kendir ve ark. 1973), açik ve kapalı ahırlarda barındırılan 1,5 ve 2,5 yașı Doğu Anadolu Kırmızısı erkeklerin günlük canlı ağırlık artışları arasında önemli bir farklılık bulunmamış, buna karşılık bir $\mathrm{kg}$ canlı ağırlık artışı için, açıkta barındirılanların daha fazla yem tükettikleri ortaya konmuştur.

Aynı Enstitüde beş farklı genotipten sığırla yürütülen bir başka çalışmada (Uludağ 1973) ise kapalı ahırda beslenen grupların günlük canlı ağırlık artışının, az da olsa, yüksek olması dışında, Kendir ve ark. (1973) tarafından tespit edilenlere benzer sonuçlar alınmıştır. Bu iki çalışmadan açık ahırda yem değerlendirmenin düştüğü şeklinde bir sonuç çıkarmak mümkündür. Fakat her grubun düşük sayılabilecek düzeyde enerji içeren rasyonla besienmiş oldukları dikkatlerden uzak tutulmamalıdır. Nitekim, araştırıcılar da oldukça büyük sayılabilecek bu farkı, açık ve kapalı ahırlarda yedirilen rasyonun, kapalı ahır dikkate alınarak düzenlenmesiyle açıklamaya çalışmıştır. Gerçekten de vücut sıcaklığını korumak ve canlı ağırlık artışı sağlamak için intiyaç duyulan enerji. günlük tüketilebilecek miktar içerisinde verilemezse, alınabilen enerjinin büyük bölümü vücut sıcaklığ̀ının korunmasına harcanacak, beklenen düzeyde ağırlık artışı gerçekleşmeyecektir. $\mathrm{Bu}$ da, doğal oiarak, yem değerlendirmeyi düşürmektedir (Birkelo ve ark. 1991, Young 1983).

Kapalı, sundurmalı ve açık ahırda 4'ü kış, 4'ü de yaz dönemlerini kapsayan 8 çalişma yürütülmüş ve bu çalışmalar bir arada değerlendirildiğinde günlük canlı ağırlık artışı; kış ve yaz dönemlerinde, kapalı ahırda 1100 $\mathrm{g}$ ve $1130 \mathrm{~g}$, sundurmalı ahırda $1090 \mathrm{~g}$ ve $1350 \mathrm{~g}$, açık ahırda ise $1000 \mathrm{~g}$ ve $1270 \mathrm{~g}$ olarak bulunmuştur (Leu ve ark. 1975). Aynı çalışmada elde edilen yem değerlendirme katsayıları ise, yine kış ve yaz dönemlerinde kapalı ahır için $5.61 \mathrm{~kg}$ ve $5.76 \mathrm{~kg}$, sundurmalı ahır için $5.49 \mathrm{~kg}$ ve $5.44 \mathrm{~kg}$, açık ahır için de $6.04 \mathrm{~kg}$ ve $5.77 \mathrm{~kg}$ olarak saptanmıştır (Leu ve ark. 1975).

Açık, kapalı-serbest ve kapalı-bağlı duraklı ahırların besi performansına etkisini incelemek amacıyla yürütülen bir çalışmada (Hotaman 1991) ; grupların günlük canlı 
ağırlık artışı sırasıyla $1439 \mathrm{~g}, 1232 \mathrm{~g}$ ve $1252 \mathrm{~g}$, yine aynı sırayla günlük yem tüketimi ise $9.4 \mathrm{~kg}, 8.0 \mathrm{~kg}, 8.5 \mathrm{~kg}$ olarak bulunmuştur. Bu çalışmada elde edilen yem değerlendirme katsayıları ise birbirine oldukça yakındır $(6.8 \mathrm{~kg}, 6.8 \mathrm{~kg}$ ve $6.5 \mathrm{~kg})$

Tarla Bitkileri Merkez Araştırma Enstitüsü ahırında yaz, sonbahar, kış ve ilkbahar mevsimlerinin başlarında besiye alınan hayvanlarla yürütülen bir çalışmada, SiyahAlaca erkek danaların besi performansı ile kesim ve karkas özelliklerine mevsimin etkisini incelenmiştir (Başaran 1994). Hayvanlar 450 kg'a ulaştıklarında sonlandırılan beside yaz, sonbahar, kış ve ilkbaharda besiye alınanlarda günlük canlı ağırlık artışı sırasıyla 1103 g. $1067 \mathrm{~g}, 1049 \mathrm{~g}$, ve $1352 \mathrm{~g}$ bulunurken, yem değeriendirme katsayısı yine aynı sırayla $7.1 \mathrm{~kg}, 7.4 \mathrm{~kg}$, $7.7 \mathrm{~kg}$ ve $5.9 \mathrm{~kg}$ olmuştur.

Yaklaşık 8-8,5 aylık yaşta Siyah Alaca erkek danalarla iki farklı mevsimde başlatılan ve her mevsim üç değişik barınak tipinde sürdürülen bu çalışmanın amacı; barınak tipi ve besiye başlama mevsiminin besi performansı ile kesim özelliklerine etkisini belirlemektir.

\section{Materyal ve Yöntem}

Biri kış diğeri de yaz mevsimini kapsayan iki dönemde yürütülen çalışmanın hayvan materyalini toplam 42 baş Siyah Alaca erkek dana oluşturmuştur. Bu hayvanların ilk yarısı yaklaşık 7-30 günlük yaşta Polatlı Tarım Işletmesi Müdürlüğünden satın alınarak araştırmanın yürütüldüğü Tarla Bitkileri Merkez Araştırma Enstitüsüne (TARM) getirilmiş ve burada besi başı yaşı olarak düşünülen 8 aya kadar normal koşullarda büyütülmüştür. Ikinci grup ise, denemenin yaz bölümü başlatıldığında hayvanlar 8 aylık yaşta olacak şekilde, yine Polatı Tarım Iş̧letmesi Müdürlügüunden, 7-30 günlük yaşlarda satın alınarak TARM'ne getirilmiş, birinci grupla benzer koşullar da büyütülmüștür.

Denemede kullanılan rasyon üç temel bileşenden oluşturulmuştur. Bunlardan arpa kırması deneme süresince adibitum düzeyde, arpa samanı ise günde, hayvan başına toplam $1 \mathrm{~kg}$ olacak şekilde, iki öğünde yedirilmiştir. Üçüncü bileşen olan karma yem (Çizelge 1)
Çizelge 1. Denemede kullanılan karma yemin yapısı

\begin{tabular}{|l|c|}
\hline Hammadde & Karma yemdeki payı (\%) \\
\hline Arpa & 20 \\
\hline Buğday & 25 \\
\hline Kepek & 10 \\
\hline Ayçiçeği tohumu küspesi & 20 \\
\hline Pamuk tohumu küspesi & 20 \\
\hline Mineral ön karması & 0.5 \\
\hline Vitamin ön karması & 0.5 \\
\hline Tuz & 1.5 \\
\hline Mermer tozu & 2.5 \\
\hline
\end{tabular}

Enstitünün yem yapım ünitesinde hazırlanmış ve besi süresince hayvan başına günde iki $\mathrm{kg}$ olarak, yine iki ögünde verilmiştir.

Gruplarda yer alan hayvanların karma yem tüketimine alıştırııması için, besiye başlama tarihinin yaklaşık üç hafta öncesinden başlayarak, rasyonda arpa miktarı yavaş yavaş artırıımış, hayvanların ad-libitum düzeyde arpa kırması tüketecek duruma gelmeleri sağlanmıştır. Ayrıca besi başlangıcında bütün hayvanlarda iç ve dış parazit mücadelesi yapılmıştır.

Farki barınak tiplerinin besi performansı ve kesim özelliklerine etkilerini ortaya koymak amacıyla planlanan çalışma açık, yarı açık ve kapalı olarak tanımlanan üç farklı barınakta, Çizelge 2'de gösterildiği gibi hem kış hem de yaz dönemini kapsayacak şekilde yürütülmüştür.

Her dönem yaklaşık 8 aylık yaşta toplam 21 baş Siyah-Alaca erkek dana, önce rasgele 7 'şer başlık 3 gruba ayrılmıştır, daha sonra bu grupların hangi barınakta tutulacağı kura çekilerek belirlenmiştir.

Yeme alıştırma döneminin son üç gününde, sabah yemlemesinden önce, bütün hayvanlar tartılmış ve tartımlarin ortalaması besi başı ağırığı olarak kabui edilmiştir. Toplam 168 gün (24 hafta) sürdürülen beside, hayvanlar 4 haftada bir, yine sabah yemlemesinden önce, tartılmışlardır.

Çizelge 2. Besi dönemi, barınak tipleri ve barınakların özellikleri

\begin{tabular}{|c|c|c|}
\hline Besi dönemi & Barinak tipleri & Barınak tiplerinin genel özellikleri \\
\hline $\begin{array}{l}18 \text { Ekim-1993 } \\
4 \text { Nisan } 1994\end{array}$ & $\begin{array}{l}\text { Açık } \\
\text { Yanı açık } \\
\text { Kapail }\end{array}$ & \multirow[t]{2}{*}{$\begin{array}{l}\text { Açık: } 12 \mathrm{m \times 17m} \text {, bir tarafı kapalı sundurma yok. } \\
\text { Yarı açık: } 8 \times 17 \mathrm{~m} \text { üç tarafı ve üstü kapalı sundurma }+12 \mathrm{~m} \times 17 \mathrm{~m} \text { açik bölme }\end{array}$} \\
\hline $\begin{array}{l}2 \text { Mayıs-1994 } \\
17 \text { Ekim } 1994\end{array}$ & $\begin{array}{l}\text { Açık } \\
\text { Yarı açık } \\
\text { Kapalı }\end{array}$ & \\
\hline
\end{tabular}


Besi tamamiandığında da sabah yemlemesinden önce yine üç gün üst üste yapılan tartımların ortalaması besi sonu ağırlığı olarak alınmıştır. Besi sonunda her gruptan, ağırlığı giup ortalamasına yakın 3 baş hayvan 24 saat aç bırakıldiktan sonra - su serbest- tartılarak kesimhane ağırlığı belirlenmiştir. Daha sonra bu hayvanlar Enstitü kesimhanesinde kesilmiş ve kesim özelliklerine ait veriler toplanmıştır.

Deneme süresince her dönemde tespit edilen yem tüketimleri ve canlı ağılıklardan yararlanılarak besi performansını ortaya koyacak çeşitli değerler hesaplanmiştır.

Araştırma süresince sıcaklık ve yağış ölçümleri denemenin yürütüldüğü Enstitüye komşu olan Topraksu Araştırma Enstitüsü (Lodumlu) Meteoroloji istasyonundan eide edilmiştir.

Yem tüketimi grup düzeyinde saptandığından, hem bu özellik hem de yem değerlendirme katsayısı için sadece grup ortalamalanı verilebilmiştir. Besi performansı ve kesim özelliklerine mevsim ve barınak tipinin etkisini ortaya koyabilmek için veriler aşağıdaki istatistik modele göre analiz edilmiştir (Harvey 1987).

$Y_{i j k}=\mu+a_{i}+b_{j}+(a b)_{i j}+e_{i j k}$

Burada ;

$Y_{i j k}$ i. mevsim j. barınak tipinde barındırılan $k$. bireyin değerini (canlı ağırlık, günlük canlı ağılık artışı v.b),

$\mu=$ Genel ortalama,

$a_{i}=$ Mevsimin i. halinin etki miktarı $(i=1,2)$,

$b_{j}=$ Barınak tipinin j. halinin etki miktarı $(j=1,2,3)$, miktarını,

$(a b)_{i j}=\mathrm{i}$. Barınak tipi j. mevsim interaksiyonun efki

$e_{i j k}=i . m e v s i m j$. barınak tipinde barındırılan $k$. bireye etkili tesadüfi çevre faktörlerinin etki miktarını $(0, \delta 2 \mathrm{e})$, ifade etmektedir.

Gruplar arası (mevsimler, barınaklar) farklilık önemli bułunduğunda, farklı grupları belirlemek için Duncan testine başvurulmuştur.

\section{Bulgular ve Tartışma}

Araştırma bulguları besi gücü, yem değerlendirme ve kesim özellikleri alt başlıklarında incelenecektir.

\section{Besi gücü}

Besi gücünü ifade etmek için üzerinde durulan besi sonu canlı ağırlığı, beside kazanılan toplam canlı ağırlık ve günlük ortalama canlı ağırlık arţşına ait en küçük kareler ortalaması Çizelge 3'te verilmiştir. Bütün gruplarda, besi başı ağırlığı birbirine oldukça yakın ve bes süresi sabit olduğundan, besi gücünün ölçüleri olarak kabul edilen bu üç özellik birbirleriyle bağlantılı hale gelmiştir. Dolayısıyla, bunlardan birine ilişkin bir değerlendirme, büyük ölçüde diğerleri için de geçerlidir.
Mevsimler ayrı ayrı değerlendirildiğinde; kış mevsiminde kapaiı ve yarı açık barınakta tutulanların ortalama günlük canlı ağırlık artışiarının birbirine oldukça yakın, açık ahırda barındırılanların günlük canlı ağırlık artışının ise bunlardan yaklaşık $100 \mathrm{~g}$ daha düşük olduğu görülmektedir.

Besi süresindeki 4'er haftalık periyotlar incelendiğinde bu düşüklüğün her her dönemde ortaya çıkmadığı, 10 Ocak - 6 Mart tarihlerini kapsayan 85-140. günler arasındaki farklılıktan kaynaklandığı anlaşımaktadır. Bu tarihler arasındaki dönem, besi süresindeki en düşük sıcaklık dereceleri ile en fazla karlı ve karlı-yağmurlı günlerin gerçekleştiği dönemdir (Çizelge 5). Ilik bakışta bu durum açık barınağın bir dezavantajı gibi görülürse de, besinin bir-iki dönem daha sürdürülmesi söz konusu olduğunda, farkın kapanması da beklenebilir (Akcan ve ark. 1992). Bu nedenle daha doğru değerlendirmelere imkan sağlayabilmek için, benzer çalışmalarda, besi döneminin biraz uzatııması (28-42 gün) yarariı olacaktır.

Yaz mevsiminde başlatılan beside sağlanan ortalama günlük canlı ağırık artışı, açık, yarı açık ve kapalı barınaklarda sırasıyla 1103, 1291 ve $1244 \mathrm{~g}$ olarak hesaplanmıştır (Çizelge 3). Bu sonuçlar kış aylarında devam eden beside, açık sistem aleyhine ortaya çıkan yaklaşık 100 g'ık farkın yaz aylarında büyüdüğünü, kapalı ahıra göre $140 \mathrm{~g}$, yarı açık ahıra göre de 190 g'a çıktığını göstermektedir. Ayrıca bu farkın belirli bir döneme özgü bir azalmayla açıklanma şansı da pek yoktur. Gerçektende kıફ̧ mevsiminde bașlatılanın aksine yaz mevsiminde başlatılan beside açık ahırda barındırılan grubun günlük canlı ağırlık artışı, hemen her besi döneminde, diğer grupların bazen birinden bazen de her ikisinden daha düşük olmuştur.

Mayıs ayının ilk günlerinde başlatılan yaz grubunun her döneminde oldukça yüksek sicaklik dereceleri saptanmıştır (Çizelge 5). Bunun açıkta barındırılanları olumsuz etkilediği düşünülebilir. Buna ek olarak, yarı açıkta barındırılanların, hern kış hem de yaz döneminde en yüksek değeri göstermeleri ve açıkta barındırılan yaz grubunun, kış grubundan daha düşük değerli olması, azından Ankara koşullarında, soğuğun sıcak kadar clumsuzluğa neden olmadığı şeklinde de değerlendirilebilir. Toplam ağırık artışı, besi sonu ağırlı̆ı ve günlük canlı ağırık artışı bakımından en düşük değer, açık ahırda beslenenlerden elde edilmiştir $(P<0.05)$. Bu üç özellikte de yarı açık ahırda elde edilen ortalama değerler kapalı ahırda elde edilenlerden yüksektir. Ne varki bu üstünlükler önemli bulunmamıştır $(p>0.05)$.

Farklı barınak tiplerinin besi gücü üzerine etkisini araştırmaya yönelik çalışmaların önemli bir kısmında kapalı barınaklarla açık barınaklar arasında önemli farklııklar bulunmadığı belirtilmiştir (Kendir ve ark. 1973, Hotaman 1991, Tüzemen ve ark. 1992, Akcan ve ark. 1992. Buclin ve ark. 1992, Başaran 1994). 
Çizelge 3. Besi başı yaşı ve ağırlığı ile besi gücüne ilişkin özelliklere ait en küçük kareler ortalaması

\begin{tabular}{|c|c|c|c|c|c|}
\hline \multirow{2}{*}{ Faktörler ve halleri } & \multicolumn{3}{|c|}{$\ddot{0}$} & $r$ & \multirow[b]{2}{*}{$\begin{array}{l}\text { Günlük canlı ağırlık artışı } \\
\text { (g) }\end{array}$} \\
\hline & $\begin{array}{c}\text { Besi başı yaşı } \\
\text { (Ay) }\end{array}$ & $\begin{array}{c}\text { Besi başı } \\
\text { ağırlığı } \\
(\mathrm{kg})\end{array}$ & $\begin{array}{c}\text { Besi sonu } \\
\text { ağırliğı } \\
(\mathrm{kg})\end{array}$ & $\begin{array}{l}\text { Beside ağırlık kazancı } \\
(\mathrm{kg})\end{array}$ & \\
\hline Besi başı mevsimi & $P<0.05$ & O.D & O.D & O.D & O.D \\
\hline $\mathrm{K} ı \mathrm{~s}$ & 8.44 & 218.4 & 427.3 & 208.9 & 1243.0 \\
\hline Yaz & 8.02 & 219.0 & 422.7 & 203.7 & 1213 \\
\hline Barınak & Ó.D & O.D & $P<0.05$ & $P<0.05$ & $P<0.05$ \\
\hline Açık & 8.24 & 218.9 & $410.2^{\mathrm{a}}$ & $191.2^{a}$ & $1138^{a}$ \\
\hline Yarı açık & 8.19 & 219.4 & $435.4^{b}$ & $216.1^{b}$ & $1286^{b}$ \\
\hline Kapalı & 8.26 & 217.7 & $429.4^{\text {ab }}$ & $2116^{b}$ & $1260^{b}$ \\
\hline Mevsim-barınak & $O . D$ & O.D & $O . D$ & Ö.D & Ö.D \\
\hline Kış-açık & 8.50 & 218.6 & 415.7 & 197.1 & 1173 \\
\hline Kış-yan açık & 8.40 & 219.3 & 434.6 & 215.3 & 1281 \\
\hline Kış-kapaiı & 8.41 & 217.3 & 431.6 & 214.3 & 1276 \\
\hline Yaz-açık & 8.00 & 219.3 & 404.7 & 185.3 & 1103 \\
\hline Yaz-yanı açık & 8.00 & 219.4 & 436.3 & 216.9 & 1291 \\
\hline Yaz-kapalı & 8.11 & 218.1 & 427.1 & 209.0 & 1244 \\
\hline
\end{tabular}

Bir faktörün halleri için aynı sütunda değişik harf taşıyanlar arasındaki farklılık önemlidir.

Ö.D: Bu faktörün halleri arasındaki farklilik önemsizdir.

Çizelge 4. Besi süresince çeşitli dönemlerde günlük canlı ağırlık artışı

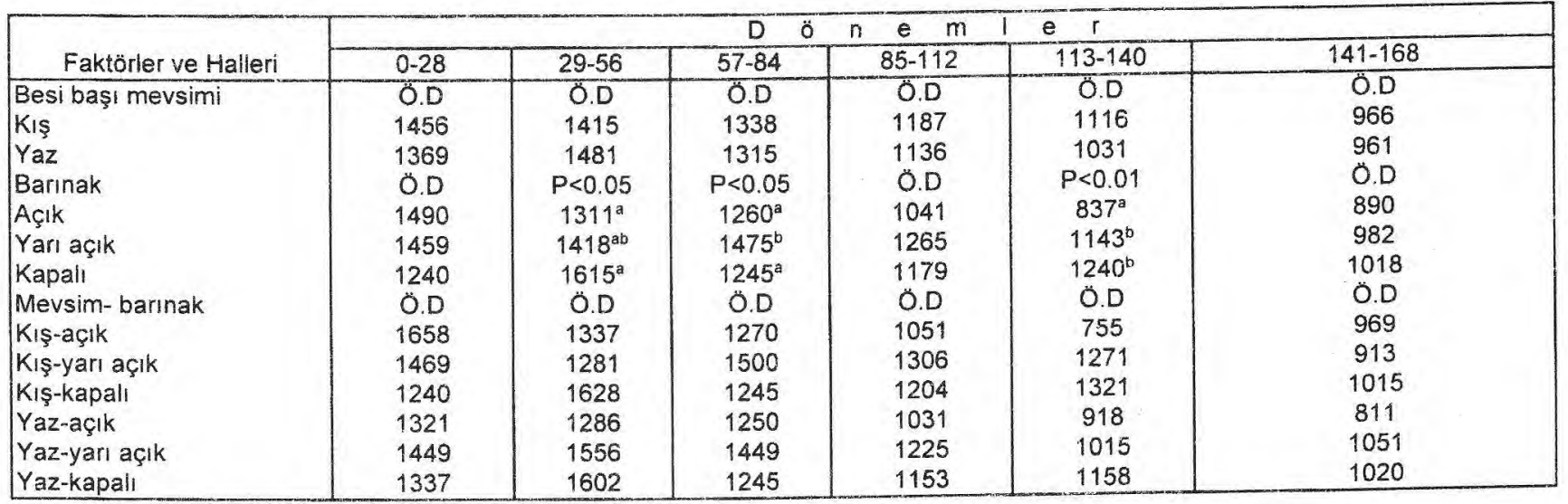

Bir faktörün halleri için aynı sütunda değişik harf taşıyanlar arasındaki farklılık önemlidir.

O.D: Bir faktörün halleri arasındaki farklılik önemsizdir.

Çizelge 5. Araştırma dönemine ait bazı meteorolojik veriler

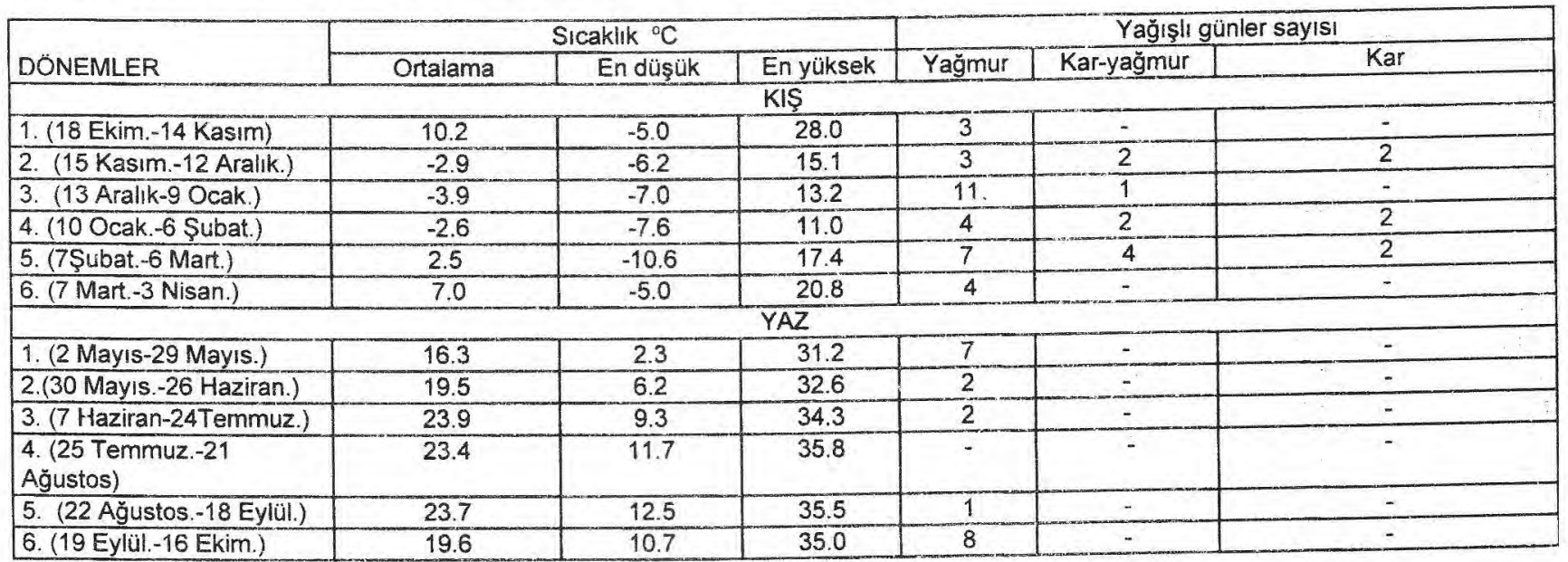




\section{Yem tüketimi ve yem değerlendirme}

Daha önce belirtildiği gibi bütün gruplara besi süresince günde $1 \mathrm{~kg}$ arpa samanı ile bileşimi Çizelge 1 'de verilen karma yemden $2 \mathrm{~kg}$ verilmiştir. Dolayısıyla rasyonun bu bileşenleri bakımından, gruplar arasında bir farklılık söz konusu değildir. Hem günlük tüketim hem de 1 kg ağırık artışı için tüketim bakımından görülen farklılık, rasyonda tüketimine sınırlama konmayan tek bileşen olduğundan, arpa olarak ifade edilebilir. Çizelge 6 'da yer alan değerler arpa tüketimine $2 \mathrm{~kg}$ karma yem ile $1 \mathrm{~kg}$ saman eklenerek bulunmuştur, Farklı rasyonlarla yürütülen besi çalışmalarının sonuçları ile, daha kolay karşılaştırma yapılabileceği düşünülerek, hem toplam yem tüketimi, hem de yem değerlendirme katsayısı kuru madde esas alınarak hesaplanmıştır.

Yem tüketimi grup düzeyinde belirlendiğinden, daha önce de belirtildiği gibi, istatistik değerlendirme yapılamamış, dönemlere ve besinin tümüne ait yem tüketimi ve yem değerlendirme ortalamaları verilmiştir (Çizelge 6). Çizelgede yer alan ortalama kurumadde tüketimlerine bakıldığına, kış mevsiminde günlük tüketimin fazla olduğu görülmektedir. Barınak tipleri dikkate alınarak bir değerlendirme yapıldığında ise, hem yaz hem de kış döneminde, açık ahırda gerçekleşen tüketim yüksek bulunmuştur. En düşük güniük tüketimle en yüksék günlük tüketim arasındaki fark $320 \mathrm{~g}$ kuru maddeye eşdeğerdir.

Bir kg canlı ağırlık artışı için yem tüketimi (yem değerlendirme katsayısı) dikkate alınarak bir inceleme yapıldığında açık ahırda elde edilen sonucun diğerlerinden az olduğu görülmektedir. Gerçekten de kış döneminde yarı açık ve kapalı ahırda $1 \mathrm{~kg}$ canlı ağırık artışı için yaklaşık $6.5 \mathrm{~kg}$ kuru madde tüketilirken, açık ahırda bu değer $7.2 \mathrm{~kg}$ olmuştur. Yaz döneminde ise yarı açık ahırda $6.3 \mathrm{~kg}$, kapalı ahırda $6.5 \mathrm{~kg}$ kuru madde tüketimi ile $1 \mathrm{~kg}$ ağırlık artışı sağlanırken, açık ahırda $1 \mathrm{~kg}$ artış için $7.5 \mathrm{~kg}$, kuru madde tüketilmiştir.

Bir kg canlı ağırlık artışı için kuru madde tüketimde ortaya çıkan bu durum, hemen bütün periyotlarda yem tüketimi bakımından gruplar arasında önemli farklııklar olmadığı dikkate alınarak, günlük canlı ağırlık artışında görülen değişmelerle açıklanabilir. Bir başka ifade ile günlük canlı ağırlık artışında önemli azalmaların görüldüğü dönemler yem değerlendirmenin azaldığı dönemlerle çakışmaktadır. Yem değerlendirme bakımindan en ilginç sonuç; açik sistemle yarı açık sistem arasında kış aylarında sürdürülen beside $700 \mathrm{~g}$ olan farkın, yaz aylarında sürdürülen beside 1000 grama çıkmasıdır. Bu da kısaca sıcağın, daha önemli bir stres unsuru olduğu şeklinde değerlendirilebilir.

\section{Kesim özellikleri}

Daha önce belirtildiği gibi her gruptan, grup ortalamasına yakın üç baş hayvan kesilerek kesim özellikleri belirlenmeye çalışımıştır. Açık, yarı açık ve kapalı barınaklarda beslenenlerin besi sonu ağılıklarına bağlı olarak, kesimhane ağırlıkları da farklı bulunurken $(P<0.05)$, randıman, bütün gruplarda birbirine oldukça yakın hesaplanmıştır (Çizelge 7). Bu durum kesimhane ağırlıklarında görülen farklılığın sıcak karkas ağırlığına da yansımasına neden olmuş ve en düşük karkas ağırlığı açık ahırda barındırılanlardan elde edilmiştir.

Iç yağ ve bc̈brek leğen boşluğu yağları bakımından bir paralellik görülmüş, hem iç yağ hem de böbrek leğen boşluğu yağları kış mevsiminde beslenenlerde daha yüksek bulunmuştur. Aynı şekilde kapali ahırda beslenenlerin de iç yağ ve böbrek leğen boşluğu yağları daha fazla olmuştur.

Çizelge 6. Yem tüketimi ve yem değerlendirme katsayıs!

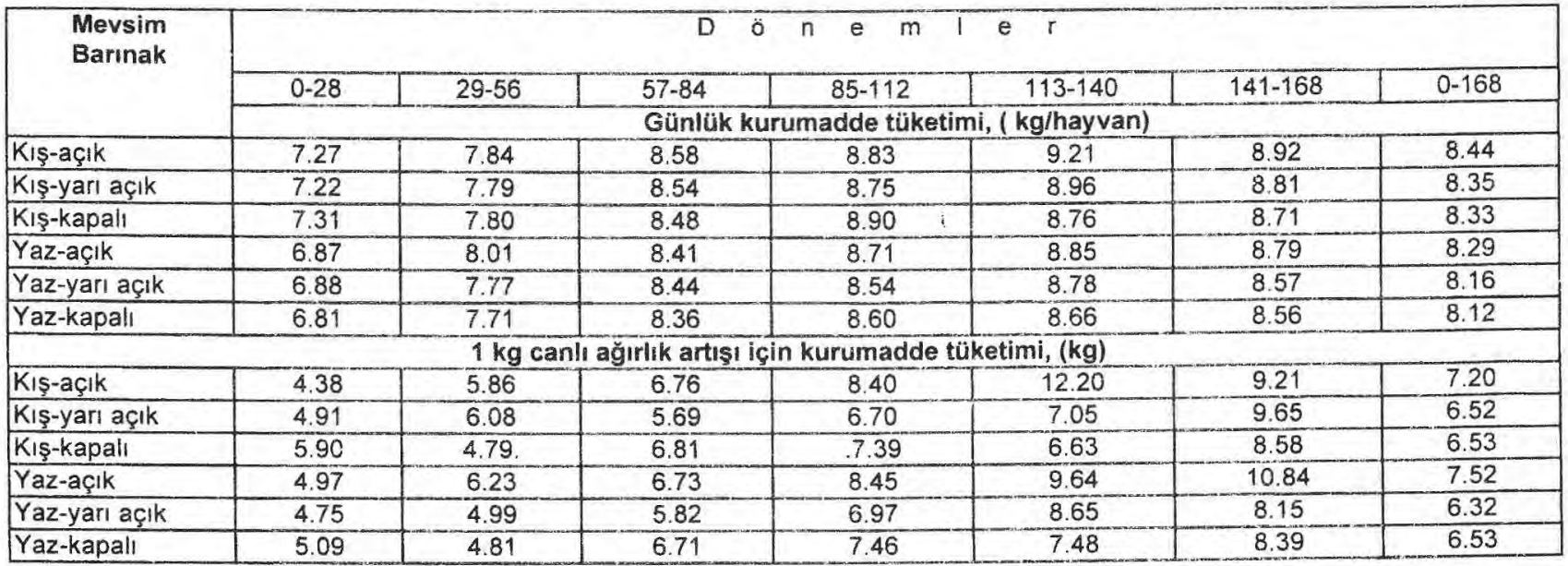


Çizelge 7. Kesim özeliiklerine ait en küçük kareler ortalaması

\begin{tabular}{|c|c|c|c|c|c|c|c|}
\hline \multirow[b]{2}{*}{ Faktör } & \multirow{2}{*}{$\begin{array}{l}\text { Kesimhane } \\
\text { ağırığı } \\
(\mathrm{kg})\end{array}$} & \multicolumn{2}{|c|}{$\begin{array}{c}\text { Karkas ağırlığı } \\
(\mathrm{kg})\end{array}$} & \multicolumn{2}{|c|}{$\begin{array}{c}\text { Randiman } \\
(\%)\end{array}$} & \multirow{2}{*}{$\begin{array}{c}\text { lç yağ ağırlığı } \\
(\mathrm{kg})\end{array}$} & \multirow{2}{*}{$\begin{array}{c}\begin{array}{c}\text { Böbrek leğen boşluğu } \\
\text { Yağları }\end{array} \\
\begin{array}{c}\text { yağları } \\
(\mathrm{kg})\end{array}\end{array}$} \\
\hline & & Sicak & Soğuk & Sicak & Soğuk & & \\
\hline Besi başı mevsimi & Ō.D & $P<0.05$ & Ö.D & $P<0.05$ & Ō.D & $P<0.01$ & $P<0.01$ \\
\hline Kış & 413.3 & 246.6 & 236.0 & 59.6 & 57.1 & 4.9 & 4.7 \\
\hline Yaz & 405.9 & 239.1 & 229.7 & 58.9 & 56.6 & 2.8 & 3.5 \\
\hline Barınak & $P<0.01$ & $P<0.01$ & $P<0.01$ & O.D & Ö.D & $P<0.01$ & $P<0.01$ \\
\hline Açık & $397.5^{\mathrm{a}}$ & $234.2^{\mathrm{a}}$ & $224.8^{\mathrm{a}}$ & 58.9 & 56.6 & $3.5^{\mathrm{a}}$ & $3.5^{\mathrm{a}}$ \\
\hline Yarı-açık & $420.3^{b}$ & $250.5^{b}$ & $240.2^{b}$ & 59.5 & 57.1 & $3.6^{\mathrm{a}}$ & $4.2^{b}$ \\
\hline Kapalı & $411.0^{b}$ & $243.8^{b}$ & $233.5^{\mathrm{b}}$ & 59.3 & 56.8 & $4.6^{\mathrm{b}}$ & $4.6^{b}$ \\
\hline Mevsim-barınak & O.D & O.D & O.D & O.D & O.D & Ó.D & O.D \\
\hline Kış-açık & 401.7 & 237.7 & 228.3 & 59.2 & 56.8 & 4.6 & 4.0 \\
\hline Kış-yarı açık & 4227 & 253.0 & 242.0 & 59.7 & 57.3 & 4.7 & 4.8 \\
\hline Kıș-kapalı & 415.7 & 249.0 & 237.7 & 59.9 & 57.2 & 5.5 & 5.2 \\
\hline Yaz-açık & 393.3 & 230.7 & 221.3 & 58.6 & 56.3 & 2.3 & 3.0 \\
\hline Yaz-yarı açık & 418.0 & 248.0 & 238.3 & 59.3 & 57.0 & 2.5 & 3.6 \\
\hline Yaz-kapalı & 406.3 & 238.7 & 229.3 & 58.7 & 56.4 & 3.7 & 4.0 \\
\hline
\end{tabular}

Bir faktörün halleri için aynı sütunda değişik harf taşıyanlar arasındaki farklıık önemlidir.

Ö.D: Bu faktörün halleri arasindaki farklilik önemsizdir.

\section{Sonuç}

Orta Anadolu koşullarında yürütülen çalışmada üç farklı barınak tipinde, hem kış hem de yaz döneminde, elde edilen ortalama güniük canlı ağırlık artışları Türkiye'de bu genotip için bildirilen değerlere oldukça yakındır (Hotaman 1991, Başaran 1994, Koçak ve ark. 1995, Akbulut ve ark. 1995). Aynı durum yem değerlendirme ve kesim özellikleri için de geçerlidir. Ayrica en düşük sıcaklığın $-10.6{ }^{\circ} \mathrm{C}$, en yüksek sıcaklığın da $+35.8^{\circ} \mathrm{C}$ olarak ölçüldüğü besi döneminde soğuktan kaynaklanan bir problem karşılaşı ımamışır. Her üç barınak tipi bir arada değerlendirildiğinde besi gücüne ilișkin özelikler bakımından besi mevsimleri arasında bir farklılık saptanamamıștır. Barınak tipleri incelendiğinde ise iyiden kötüye doğru; yarı-açık, kapalı ve açık sıralaması, çoğu önemli özellik için geçerli olmuştur. Bu hususlar dikkate alınarak; her üç sistemin de besiye alınan sığırlar için zararlı olmadığı söylenebilirse de; yetiştirici geleneğine yakınlığı, işçilik ihtiyacının düşük olması, yatırım maliyetinin azlığı ve kapalı barınaklarda ufak değişikliklerle elde edilebilmesi gibi avantajları dikkate alınarak besicilere yarı açık sistem güvenle önerilebilir.

\section{Kaynaklar}

Akbulut, Ö., N. Tüzemen, R. Aydın, 1995. Esmer ve Siyah-Alaca Tosunların açık ahırda besi performansı ve karkas özellikleri. I. Besi Performans!. Türk Veterinerlik ve Hayvancilık Derg. 19(6):409-416.

Akcan, A., O. Alpan, R. Arpacık, Y. Deliömeroğlu, 1992. Simental erkek danaların besi performanslarının açık ve kapalı ahır sistemlerinde karşıiaştırıması.. (TÜBITAKVHAG Sonuç raporu) Proje No:ETÜBAR-9.
Akcan, A. 1986. Hayvan barinaklarında barınak havası ve verimler üzerine etkisi. Hayvancilık Sempozyumu 5-8 Mayıs, Tokat

Başaran, A. H. 1994. Holstayn erkek danalarda mevsimin besi performansı, kesim ve karkas özellikleri ile besi maliyetine etkisi. (Doktora Tezi), A.U..Sağlık Bilimleri Ens.,Ankara.

Birkelo, C.P., D.E. Johnson, H.P. Phetteplace, 1991. Maintenance requirements of beef cattle as affected by season on differing planes of nutrition. J.Anim. Sci, 69: 1214-1222.

Buclin, R. A., G.L. Hahn, D.K. Beede, D.R. Bray,.: Physical facilities for warm climates. Large Dairy Herd Managment: 609-618. 1992 (ISBN 0-9634491-0-9).

Butchbaker, A.F,, G.W.A. Mohoney, J.E. Cartori, 1973. Climate and the selection of a beef housing and managment system. Trancsactions Am. Soc. Agric. Erigineers 4:734-739.

Hardy, R., S. Meadowcraft, 1986. Indoor Beef Production Farming Press Ltd., United Kingdom.

Harvey, W.R. 1987. User's Guide for LSMLMW, PC1 Version, Ohio State Univ. Columbus, USA.

Hotaman, H. 1991. Ankara şartlarında farklı barındırma sistemlerinin sığırların besi performansına etkileri. (Yüksek Lisans Tezi), A.Ü.Fen Bilimieri Ens., Ankara.

Kendir. H. S., S. Tenel, N. Uludağ, R. Öznacar, K. Alıç, 1973. Doğu Anadolu Kırmızısı ırkın besi performansı. IV.Bilim Kongresi Tebliğleri, TÜBiTAK Yayınları No:2. Ankara.

Koçak, D., S. Coşar, N. Tulgar, 1995. Farklı düzeylerde enerji içeren konsantre yemlerle kış mevsiminde açıkta beslenen holstayn erkek danaların besi performansı ve karkas özellikleri. Lalahan Hay. Araş. Ens. Dergi. 35 (1-2):1-20. 
Leu, B.M., M.P. Hoffman, H.L. Self, 1975. Effects of confinement on steer performance. J.Anim.Sci., 41:271.

Mutaf, S., R. Sönmez, 1984. Hayvan barınaklarında iklimsel çevre denetimi. Ege Üniv. Yay. No:428, Izmir.

Okuroğlu, M., L. Delibaş, 1986. Hayvan barınaklarında uygun çevre koşulları. Hayvancılık Sempozyumu Yayin No:16. Tokat.

Olgun, M. 1989. Serbest duraklı süt sığırı ahırlarının planlanması ve yapısal özellikieri. TIGEM, Inşaat ve Kültürteknik Dairesi Başkanlığı Yayınları. Ankara.

Robertshaw, D., 1981. The environmental aspects of housing for animal production (J. A. Clark Ed.) Butterworths London, 317.
Tüzemen, N., O. Akbulut, R. Aydın, M. Yanar, Y. Sağsöz, 1992. Açık ve kapalı ahırlarda esmer tosunların besi performansı ve karkas özellikleri. Doğa Vet. Hay. Derg., 16,(1):76-85.

Uludağ, N. 1973. Esmer, Yerlikara ve Doğu Anadolu Kırmızısı erkek danaların kapalı ve açık besi yerlerindeki besi kabiliyetleri. IV.Bilim Kongresi Tebliğleri, TÜBITAK Yayınları No:2. Ankara.

Yener, S.M. ve N. Akman, 1990. Türkiye'de sığırcilığın bugünü ve geleceği. T.O.K. Derg. 54:6-9.

Young, B.A. 1983. Cold stress as it affects animal production. J.Anim.Sci. 57:1601-1607 